\section{Turkish Journal of Zoology}

http://journals.tubitak.gov.tr/zoology/
Turk J Zool

(2015) 39: 256-262

(c) TÜBİTAK

doi:10.3906/zoo-1311-38

\title{
Distribution of hard tick species in Ankara, Turkey
}

\author{
Olcay HEKIMOĞLU, Ayșe Nurdan ÖZER* \\ Department of Biology, Ecology Division, Faculty of Science, Hacettepe University, Beytepe, Ankara, Turkey
}

Received: 21.11 .2013

- Accepted: 10.06 .2014

- $\quad$ Published Online: 27.02 .2015

- $\quad$ Printed: 27.03 .2015

\begin{abstract}
A systematic study has been carried out on hard ticks from Ankara Province, Turkey. Between April 2010 and July 2012, 1800 tick specimens belonging to 9 species were identified at 31 locations in 9 districts. Tick species are listed as follows: Rhipicephalus sanguineus group (43.44\%), Rhipicephalus bursa (36.67\%), Hyalomma marginatum (8.83\%), Haemaphysalis parva (6\%), Hyalomma aegyptium (2.39\%), Hyalomma excavatum (1.33\%), Dermacentor marginatus (1.06\%), Haemaphysalis punctata (0.22\%), and Hyalomma detritum $(0.06 \%)$. Ticks were collected from host animals and from vegetation via the flagging method. The species of the genus Rhipicephalus were present in most of the study areas, the most common being the Rhipicephalus sanguineus group (20/31). Hyalomma species were mostly collected from host animals, with Hyalomma marginatum being the most common species in this genus (8.83\%). We also observed seasonal variations in abundance, with the highest number in May. The district with the most abundant ticks was determined to be Kizılcahamam, which had the highest tick abundance rate of $28.6 \%$.
\end{abstract}

Key words: Ankara, tick, flagging, Rhipicephalus, Hyalomma

\section{Introduction}

Ticks are obligatory blood-sucking arthropods that have an important role in human and animal health. They are potential vectors of a wide range of pathogenic microorganisms, including protozoal, rickettsial, bacterial, and viral microorganisms (Sonenshine, 1991; Jongejan and Uilenberg, 2004; Anderson and Magnarelli, 2008).

Turkey is the easternmost country in the temperate climate zone of the European continent, with a high regional climatic variation. Since the emergence of Crimean-Congo hemorrhagic fever (CCHF) in Turkey in 2002, there have been many studies focused on CCHF cases (Tonbak et al., 2006; Albayrak et al., 2010; Tekin et al., 2012; Yesilbag et al., 2013). In spite of increased case reports of tick bites and CCHF cases, information regarding the presence and distribution of certain species is still limited. The first review on the tick fauna of Turkey was published in 2007 (Aydin and Bakirci, 2007). According to this report, Turkey's tick fauna is composed of 32 species from 2 families and 10 genera. Most of the published tick studies deal with its occurrence on domestic animals (Yukarı and Umur, 2002; Yay, 2004; Bakirci et al., 2012) or humans (Gargilı et al., 2010; Bursali et al., 2010; Karaer et al., 2011; Kar et al., 2013). However, comprehensive information about tick biology and ecology should be obtained by collecting unfed ticks, as tick species prefer different host

*Correspondence: nozer@hacettepe.edu.tr species (Babos, 1965; Hornok and Farkas, 2009). The risk of humans or animals contracting CCHF disease and other tick-borne diseases might be directly linked to the questing activity of ticks. The continental climate, steppe vegetation, and domestic and wild fauna of Ankara provide suitable habitats for ticks. Additionally, CrimeanCongo hemorrhagic fever virus (CCHFV) was detected in Hyalomma marginatum and Rhipicephalus bursa in our recent study in Ankara Province, Turkey (Hekimoglu et al., 2012). Although the ticks of the region have a prominent potential for carrying tick-borne diseases, there has not been any comprehensive systematic work on hard ticks in Ankara until now. Therefore, the purpose of this study is to evaluate the ixodid tick fauna and its geographical distribution in this region.

\section{Materials and methods}

The study was performed in Ankara Province, Central Anatolia $\left(39^{\circ} 56^{\prime} \mathrm{N}, 32^{\circ} 52^{\prime} \mathrm{E}\right)$. This province covers a total surface area of $25,938 \mathrm{~km}^{2}$. In the central and southern parts of the province, the climate is continental, with steppetype vegetation. However, in the northern part of the region, the climate changes to a more humid and wet Black Sea climate, and vegetation changes to forests (generally rare oak forests). Altitude varies between 900 and $2015 \mathrm{~m}$ above sea level, and mean annual temperature is $14.4{ }^{\circ} \mathrm{C}$ 
(range: $-24.9{ }^{\circ} \mathrm{C}$ to $40^{\circ} \mathrm{C}$ ). The highest temperatures are recorded in July and August, with the coldest month being January.

The sampling was conducted monthly between April 2010 and July 2012 at 31 locations in 9 districts (Akyurt, Çubuk, Gölbaşı, Kazan, Kızılcahamam, Mamak, Nallıhan, Polatll, Pursaklar) in Ankara (Figure 1; Table 1). Average temperature and humidity parameters of the study areas are given in Figure 2.

Ticks were collected from vegetation via flagging with a $1-\mathrm{m}^{2}$ piece of white cloth in each unit. Questing ticks that attached to the cloth were removed every $5 \mathrm{~m}$ to reduce the effect of tick drop-off (Li and Dunley, 1998). Each collection period lasted for $30 \mathrm{~min}$. All tick specimens were kept alive and sorted into different Falcon tubes according to the date and collection locality. Temperature, humidity, and coordinates of each sampling site were recorded. Species identification was carried out according to the morphological characters with a Leica MZ-7.5 stereoscopic 200M dissection microscope with a DC-300 digital camera system (Karaer et al., 1997; Walker, 2003; Estrada-Peña et al., 2004). The ticks were then classified in small tubes by species and location and stored at $-80{ }^{\circ} \mathrm{C}$. The identification results were confirmed by the Ankara University Faculty of Veterinary Medicine, Department of Protozoology and Entomology.

Shannon's diversity index and species richness were calculated for each sampling site (Table 1).

\section{Results}

The study was performed in April 2010-July 2012 in 9 districts of Ankara Province. Ticks were sampled from host animals (cattle, sheep, goats, and turtles) and from vegetation by flagging (Tables 2 and 3 ).

In total, 1800 adult tick individuals were collected, including 782 R. sanguineus group, 660 R. bursa, 159 H. marginatum, 108 Hae. parva, $43 \mathrm{H}$. aegyptium, $24 \mathrm{H}$. excavatum, 19 D. marginatus, 4 Hae. punctata, and $1 H$. detritum (Figure 3).

According to monthly distributions, the highest sampling was done in May with 545 specimens (30.27\%) in 3 years. The percentage of tick specimens was found to be $26 \%$ in April, $22.94 \%$ in June, and $17.61 \%$ in July (Figure 4).

The $R$. sanguineus group was the most common tick species in the sampling areas. Adults of this species were found at 20 of the 31 locations. $H$. excavatum (4/31), D. marginatus (4/31), H. aegyptium (3/31), and Hae. punctata $(2 / 31)$ were less common, and $H$. detritum (1/31) was found in only 1 location (Table 1 ).

The most ticks were collected from the Kizilcahamam district. We collected 516 specimens (28.66\%) belonging to 7 tick species in Kizilcahamam, 401 samples $(22.2 \%)$ in Akyurt locations, 282 (15.6\%) in Kazan, 250 (13.8\%) in Pursaklar, 197 (10.9\%) in Çubuk, and 151 (8.38\%) in Polatli. No ticks were found in Gölbaşı (location numbers $10,11,12$ ) or Mamak (location number 22) districts.

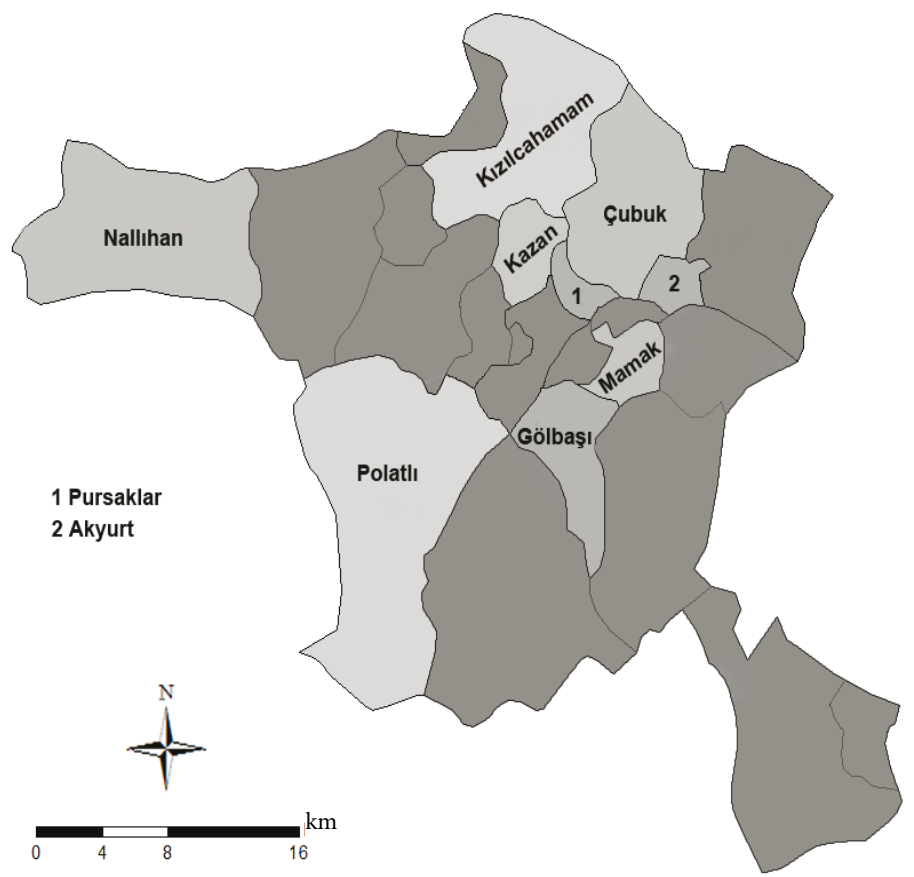

Figure 1. The locations of tick sampling districts within Ankara Province, Turkey. 
HEKİMOĞLU and ÖZER / Turk J Zool

Table 1. Distribution of tick species collected in Ankara Province during April 2010-July 2012.

\begin{tabular}{|c|c|c|c|c|c|c|}
\hline Location & Habitat & Coordinates & Altitude & Richness & Shannon & Tick species \\
\hline 1 & Rural & $40.13212^{\circ} \mathrm{N}, 33.12949^{\circ} \mathrm{E}$ & $1104 \mathrm{~m}$ & 2 & 0.27 & R. bursa, R. sanguineus group \\
\hline 2 & Urban & $40.11924^{\circ} \mathrm{N}, 33.06150^{\circ} \mathrm{E}$ & $952 \mathrm{~m}$ & 5 & 0.31 & $\begin{array}{l}\text { R. bursa, } R \text {. sanguineus group, H. aegyptium, Hae. } \\
\text { parva, D. marginatus }\end{array}$ \\
\hline 3 & Meadow & $40.05666^{\circ} \mathrm{N}, 33.04544^{\circ} \mathrm{E}$ & $984 \mathrm{~m}$ & 2 & 0.29 & R. bursa, $R$. sanguineus group \\
\hline 4 & Rural & $40.26739^{\circ} \mathrm{N}, 33.01846^{\circ} \mathrm{E}$ & $952 \mathrm{~m}$ & 2 & 0.3 & R. bursa, H. marginatum \\
\hline 5 & Rural & $40.30077^{\circ} \mathrm{N}, 32.99104^{\circ} \mathrm{E}$ & $1296 \mathrm{~m}$ & 2 & 0.3 & R. bursa, $R$. sanguineus group \\
\hline 6 & Meadow & $40.30956^{\circ} \mathrm{N}, 32.97519^{\circ} \mathrm{E}$ & $1265 \mathrm{~m}$ & 2 & 0.3 & R. bursa, H. marginatum \\
\hline 7 & Rural & $40.33383^{\circ} \mathrm{N}, 33.21582^{\circ} \mathrm{E}$ & $1008 \mathrm{~m}$ & 3 & 0.37 & R. sanguineus group, H. marginatum, D. marginatus \\
\hline 8 & Rural & $40.41733^{\circ} \mathrm{N}, 33.16460^{\circ} \mathrm{E}$ & $1088 \mathrm{~m}$ & 2 & 0.18 & R. sanguineus group, H. marginatum \\
\hline 9 & Rural & $40.18264^{\circ} \mathrm{N}, 33.03411^{\circ} \mathrm{E}$ & $1257 \mathrm{~m}$ & 4 & 0.32 & $\begin{array}{l}\text { R. sanguineus group, H. marginatum, Hae. parva, D. } \\
\text { marginatus }\end{array}$ \\
\hline 10 & Rural & $39.74113^{\circ} \mathrm{N}, 32.75352^{\circ} \mathrm{E}$ & $995 \mathrm{~m}$ & 0 & 0 & \\
\hline 11 & Urban & $39.67078^{\circ} \mathrm{N}, 32.73656^{\circ} \mathrm{E}$ & $1052 \mathrm{~m}$ & 0 & 0 & \\
\hline 12 & Urban & $39.65006^{\circ} \mathrm{N}, 32.72249^{\circ} \mathrm{E}$ & $1057 \mathrm{~m}$ & 0 & 0 & \\
\hline 13 & Field (wheat) & $40.19661^{\circ} \mathrm{N}, 32.69177^{\circ} \mathrm{E}$ & $891 \mathrm{~m}$ & 3 & 0.31 & R. bursa, R. sanguineus group, Hae. parva \\
\hline 14 & Rural & $40.32025^{\circ} \mathrm{N}, 32.70362^{\circ} \mathrm{E}$ & $980 \mathrm{~m}$ & 2 & 0.29 & R. bursa, $R$. sanguineus group \\
\hline 15 & Meadow & $40.39953^{\circ} \mathrm{N}, 32.67322^{\circ} \mathrm{E}$ & $1106 \mathrm{~m}$ & 5 & 0.61 & $\begin{array}{l}\text { R. bursa, } R . \text { sanguineus group, } H . \text { marginatum, } H . \\
\text { excavatum, Hae. parva }\end{array}$ \\
\hline 16 & Rural & $40.36668^{\circ} \mathrm{N}, 32.65835^{\circ} \mathrm{E}$ & $1146 \mathrm{~m}$ & 3 & 0.37 & R. bursa, H. marginatum, H. excavatum \\
\hline 17 & Rural & $40.33142^{\circ} \mathrm{N}, 32.45888^{\circ} \mathrm{E}$ & $807 \mathrm{~m}$ & 4 & 0.53 & R. bursa, H. detritum, H. marginatum, $H$. excavatum \\
\hline 18 & Rural & $40.38202^{\circ} \mathrm{N}, 32.57475^{\circ} \mathrm{E}$ & $951 \mathrm{~m}$ & 4 & 0.32 & $\begin{array}{l}R . \text { bursa, } R . \text { sanguineus group, } H . \text { marginatum, } D . \\
\text { marginatus }\end{array}$ \\
\hline 19 & Forest & $40.62463^{\circ} \mathrm{N}, 32.45974^{\circ} \mathrm{E}$ & $1505 \mathrm{~m}$ & 0 & 0 & \\
\hline 20 & Forest & $40.60077^{\circ} \mathrm{N}, 32.55079^{\circ} \mathrm{E}$ & $1410 \mathrm{~m}$ & 0 & 0 & \\
\hline 21 & Recreational & $40.36668^{\circ} \mathrm{N}, 32.70279^{\circ} \mathrm{E}$ & $971 \mathrm{~m}$ & 3 & 0.31 & R. bursa, R. sanguineus group, Hae. parva \\
\hline 22 & Meadow & $39.88942^{\circ} \mathrm{N}, 32.99228^{\circ} \mathrm{E}$ & $1120 \mathrm{~m}$ & 0 & 0 & \\
\hline 23 & Meadow & $40.31058^{\circ} \mathrm{N}, 31.29830^{\circ} \mathrm{E}$ & $763 \mathrm{~m}$ & 1 & 0 & H. marginatum \\
\hline 24 & Rural & $39.67176^{\circ} \mathrm{N}, 32.21992^{\circ} \mathrm{E}$ & $844 \mathrm{~m}$ & 2 & 0.3 & R. sanguineus group, H. marginatum \\
\hline 25 & Meadow & $39.65435^{\circ} \mathrm{N}, 31.98485^{\circ} \mathrm{E}$ & $675 \mathrm{~m}$ & 3 & 0.29 & R. sanguineus group, H. aegyptium, H. excavatum \\
\hline 26 & Rural & $39.79657^{\circ} \mathrm{N}, 32.10818^{\circ} \mathrm{E}$ & $875 \mathrm{~m}$ & 1 & 0 & R. sanguineus group \\
\hline 27 & Rural & $39.49066^{\circ} \mathrm{N}, 32.11345^{\circ} \mathrm{E}$ & $1010 \mathrm{~m}$ & 1 & 0 & R. sanguineus group \\
\hline 28 & Urban & $32.91779^{\circ} \mathrm{N}, 40.04893^{\circ} \mathrm{E}$ & $1043 \mathrm{~m}$ & 5 & 0.57 & $\begin{array}{l}\text { R. bursa, R. sanguineus group, H. aegyptium, Hae. } \\
\text { parva, Hae. punctata }\end{array}$ \\
\hline 29 & Recreational & $40.05656^{\circ} \mathrm{N}, 32.90729^{\circ} \mathrm{E}$ & $992 \mathrm{~m}$ & 4 & 0.43 & $\begin{array}{l}\text { R. bursa, R. sanguineus group, Hae. parva, Hae. } \\
\text { punctata }\end{array}$ \\
\hline 30 & Rural & $40.14070^{\circ} \mathrm{N}, 32.89167^{\circ} \mathrm{E}$ & $1014 \mathrm{~m}$ & 3 & 0.41 & R. bursa, R. sanguineus group, Hae. parva \\
\hline 31 & Rural & $40.13851^{\circ} \mathrm{N}, 32.92035^{\circ} \mathrm{E}$ & $995 \mathrm{~m}$ & 3 & 0.34 & R. bursa, $R$. sanguineus group, Hae. parva \\
\hline
\end{tabular}




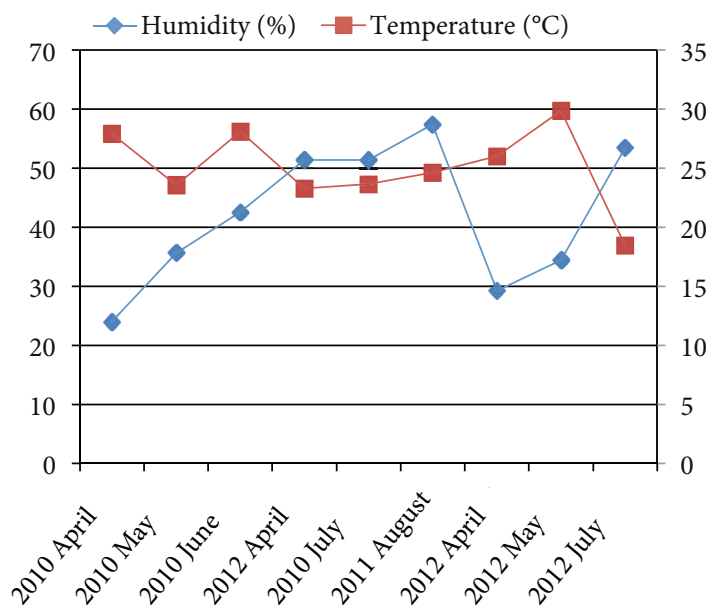

Figure 2. Temperature and humidity of Ankara during the period of study.

The species composition varied with sampling method, but no correlation was found between the species richness or Shannon's diversity and sampling method (species richness, $\mathrm{P}=0.41$; Shannon diversity, $\mathrm{P}=0.51$ ). Furthermore, neither species richness nor Shannon diversity was correlated with altitude, longitude, or latitude $(\mathrm{P}>0.05)$ (Table 1).

\section{Discussion}

In recent years, there has been a substantial increase in the number of tick-borne infection cases in Turkey; thus, the scientific studies on ticks have focused mostly on CCHF cases (Tonbak et al., 2006; Albayrak et al., 2010; Gunes et al., 2011; Hekimoglu et al., 2012; Tekin et al., 2012). In fact, continuous scanning of tick distribution is crucial in order to monitor tick-borne diseases and develop effective control strategies against them.

There has been only 1 comprehensive faunistic study describing 46 tick species in Turkey (Bursali et al., 2012), and another review study indicating 32 species from 2 families and 10 genera (Aydin and Bakirci, 2007). Several recent reports have focused mainly on ticks found on domestic animals, but not questing ticks from different areas with potentially suitable habitats. Therefore, different methods of host investigation and sampling by flagging should be used together in the same area to investigate the extensive tick fauna, as tick species show great variation in their feeding behaviors and host preferences (Anderson and Magnarelli, 2008). In addition, the tick species that show a high preference for specific host species need to be studied on their specific hosts. In studies of population dynamics, a single sampling method could be preferred.

This report documents the structure of tick communities in Ankara. Between April 2010 and July

Table 2. The distribution of the percentages for the species collected according to sampling technique.

\begin{tabular}{|c|c|c|c|}
\hline Genus & Species & Flagging & Host \\
\hline \multirow[t]{4}{*}{ Hyalomma } & H. aegyptium Linnaeus, 1758 & $0.00 \%$ & $100.00 \%$ \\
\hline & H. detritum Schulze, 1919 & $0.00 \%$ & $100.00 \%$ \\
\hline & H. marginatum Koch, 1844 & $0.6 \%$ & $99.4 \%$ \\
\hline & H. excavatum Koch, 1844 & $0.00 \%$ & $100.00 \%$ \\
\hline \multirow[t]{2}{*}{ Rhipicephalus } & R. bursa Canestrini \& Fanzago, 1878 & $78.90 \%$ & $21.10 \%$ \\
\hline & R. sanguineus group & $67.30 \%$ & $32.70 \%$ \\
\hline \multirow[t]{2}{*}{ Haemaphysalis } & Hae. parva Neumann, 1897 & $89.80 \%$ & $10.20 \%$ \\
\hline & Hae. punctata Canestrini \& Fanzago, 1878 & $100.00 \%$ & $0.00 \%$ \\
\hline Dermacentor & D. marginatus Sulzer, 1776 & $10.50 \%$ & $89.50 \%$ \\
\hline Total & & $64.00 \%$ & $36.00 \%$ \\
\hline
\end{tabular}

Table 3. The study area, the coordinates for the area, the host, and the number of specimens for H. aegyptium.

\begin{tabular}{|c|c|c|c|c|c|}
\hline Number & Study area & Coordinate & Altitude & Tortoise species & H. aegyptium specimens \\
\hline 1 & Akyurt & $\begin{array}{l}40.11924^{\circ} \mathrm{N} \\
33.06150^{\circ} \mathrm{E}\end{array}$ & $952 \mathrm{~m}$ & Testudo graeca & 10 \\
\hline 2 & Polatli & $\begin{array}{l}39.65435^{\circ} \mathrm{N} \\
31.98485^{\circ} \mathrm{E}\end{array}$ & $675 \mathrm{~m}$ & Testudo graeca & 26 \\
\hline 3 & Pursaklar & $\begin{array}{l}32.91779^{\circ} \mathrm{N} \\
40.04893^{\circ} \mathrm{E}\end{array}$ & $1043 \mathrm{~m}$ & Testudo graeca & 7 \\
\hline
\end{tabular}




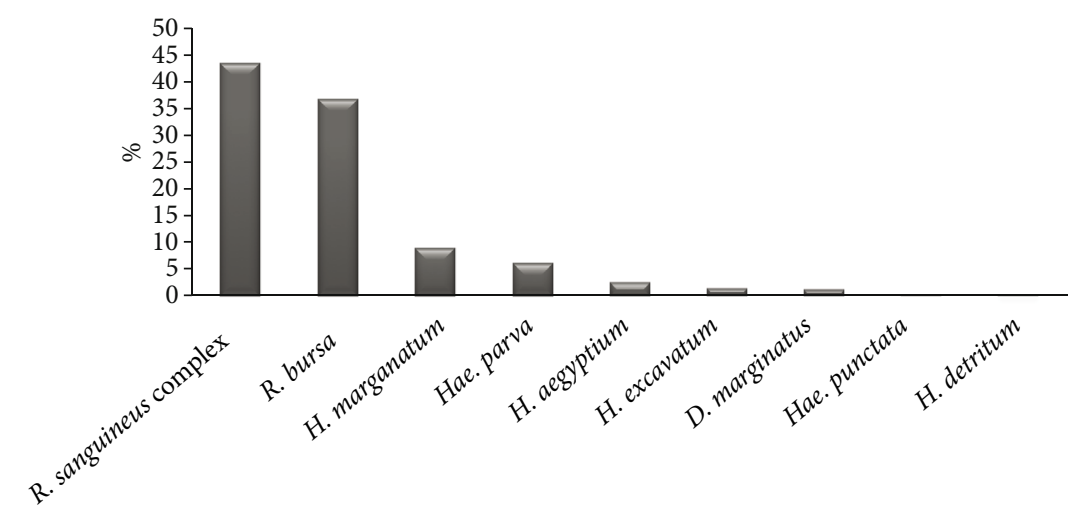

Figure 3. Tick species collected in Ankara in 2010-2012.

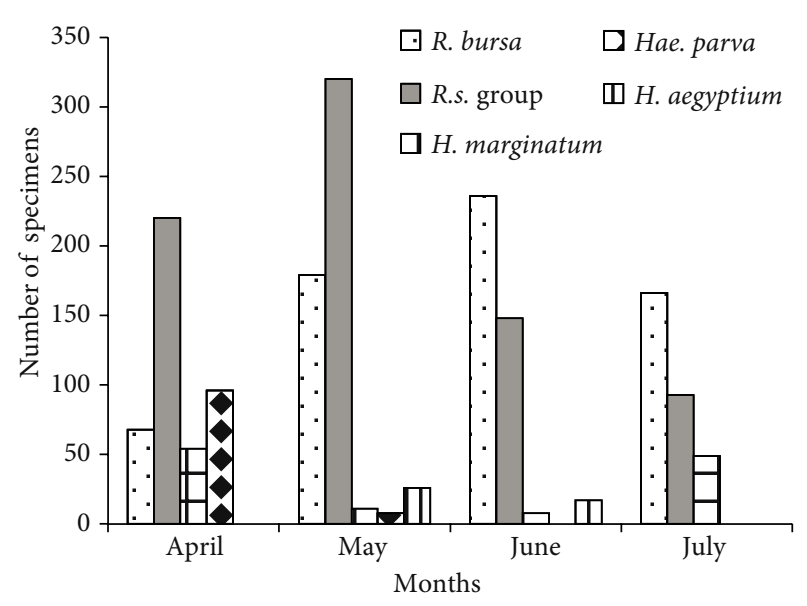

Figure 4. Seasonal abundance of ticks collected from April 2010 to July 2012 in Ankara Province.

2012, 1800 tick specimens were collected. The total number of tick species was 9 , including the $R$. sanguineus group (43.44\%), R. bursa (36.67\%), H. marginatum (8.83\%), Hae. parva (6\%), H. aegyptium (2.39\%), H. excavatum (1.33\%), D. marginatus (1.06\%) Hae. punctata $(0.22 \%)$, and $H$. detritum (0.06\%).

The variation in tick distribution in different areas is derived from a variety of factors such as climatic conditions, association and lifestyle of host animals, and habitat characterization (Ghosh et al., 2007). The most individuals were sampled from the Kizılcahamam district. The microclimatic conditions and vegetation in this district are similar to and partly continuous with those of northern/northeastern Anatolia, from where the first case of CCHF came. This district, $83 \mathrm{~km}$ from the provincial center of Ankara, is a preferred domestic tourism site for outdoor activities. We used both tick sampling methods (flagging and from host) and collected 7 tick species in this district. Generally, all sampling stations in Ankara
Province had varying vegetation cover and climate, providing suitable habitats for ticks. The absence of ticks in samples from Gölbaşı and Mamak stations might be related to inconvenient microclimatic factors during the study period (end of July).

The most prevalent species in our study were those of the $R$. sanguineus group, with an abundance of $43.44 \%$. Within the genus Rhipicephalus, the $R$. sanguineus group is one of the most important groups because of its capacity to transmit serious diseases. This complex contains 12 species (Zahler et al., 1997). Generally, Hyalomma and Rhipicephalus species were more prevalent among the ticks collected from human hosts in Turkey (Vatansever et al., 2008; Bursali et al., 2010). This conclusion is consistent with our results. However, Hae. punctata, $H$. detritum, $H$. excavatum, and D. marginatus were sampled from only some stations, and Hyalomma species could only be sampled by host examinations, not by flagging. $H$. marginatum and $H$. excavatum were collected primarily from cattle and sheep, unlike $H$. aegyptium, which was collected only from turtles. Rhipicephalus species and Hae. parva were sampled using both methods.

Among Haemaphysalis species, Hae. parva and Hae. punctata were detected in this study, but Haemaphysalis sulcata was not found; it was previously recorded in low numbers by Karaer et al. (2011) in the study area. Haemaphysalis species were collected only in April. Additionally, Hae. parva and Hae. punctata have been typically observed infesting domestic animals such as goats, sheep, and cattle in Ankara Province (Çiçek, 2004). Ticks from Ornithodoros or Otobius spp. were not detected, despite having been found in some regions in Central Anatolia previously (Aydin and Bakirci, 2007).

Ixodes ricinus, one of the most important tick species in Europe, was not detected in our study area. In Turkey, I. ricinus has been recorded in several studies (Güner et al., 2003; Masuzawa et al., 2005; Sen et al., 2005; Gargilı et al., 2006, 2007; Albayrak et al., 2010), especially in 
humid areas that have substantial secondary plant growth such as river canopies, mixed forests, and deciduous heterogeneous woods, but not in Ankara to date (EstradaPeña, 2001; Şen, 2007). According to Aydin and Bakirci (2007), I. ricinus has been observed only in rainy and forested parts of northern and northwestern Anatolia, located by the coasts of the Black Sea and the Marmara Sea, suggesting that this species is not common in Ankara in Central Anatolia.

If we look at the monthly distribution of tick samples, the greatest numbers of samples were found in May, when the mean temperature was $16.6{ }^{\circ} \mathrm{C}$, average rainfall 56.4 $\mathrm{mm}$, and average humidity $57.06 \%$. Additionally, the highest numbers of the R. sanguineus group were observed in May and June for R. bursa. The number of collected ticks was 545 (30.27\%) in May, 468 (26\%) in April, 413 (22.94\%) in June, and 317 (17.6\%) in July. Various ecological factors influence the distribution and abundance of tick vectors. High temperatures $\left(25.3^{\circ} \mathrm{C}\right)$ and low humidity $(40.7 \%)$ in August would have affected tick distribution. Ticks could be absent in August in vegetation as they might be hiding on their appropriate hosts, or they may lay eggs in cryptic habitats in the field.

In Karaer et al's study carried out in the same area in 2011, the total number of tick species was recorded as 11, but all of the samples were taken from hospitalized people who had experienced tick bites. In that study, the most common species was $H$. marginatum with a rate of $16.82 \%$, showing its feeding preference for humans (Karaer et al., 2011). According to previous studies, Hyalomma, Dermacentor, Rhipicephalus, and Haemaphysalis species constituted the majority of species collected from humans

\section{References}

Albayrak H, Ozan E, Kurt M (2010). An antigenic investigation of Crimean-Congo hemorrhagic fever virus (CCHFV) in hard ticks from provinces in northern Turkey. Trop Anim Health Prod 42: 1323-1325.

Anderson JF, Magnarelli LA (2008). Biology of ticks. Infect Dis Clin N Am 22: 195-215.

Aydin L, Bakirci S (2007). Geographical distribution of ticks in Turkey. Parasitol Res 101: 163-166.

Babos S (1965). Fauna Hungariae. Vol. XVIII. Arachnoidea. TicksIxodidae. Budapest, Hungary: Academic Press (in Hungarian).

Bakirci S, Sarali H, Aydin L, Eren H, Karagenc T (2012). Distribution and seasonal activity of tick species on cattle in the west Aegean region of Turkey. Exp Appl Acarol 56: 165-178.

Bursali A, Keskin A, Tekin S (2012). A review of ticks (Acari: Ixodida) of Turkey: species diversity, hosts and geographical distribution. Exp Appl Acarol 57: 91-104. and the field (Aydin and Bakirci, 2007; Karaer et al., 2011). These results are also in accordance with our studies.

The other studies that have been conducted in Ankara Province (Güler, 1982; Zeybek and Kalkan, 1984; Sayın and Karaer, 1987) were performed using only one method and certain hosts. It is certain that it is not possible to perform a faunal study with just one genus. In our study, we used both sampling techniques used everywhere in the world and we collected our samples from different hosts.

In this study, we evaluated the species diversity (Shannon diversity) and species richness of ixodid ticks in study areas in Ankara. Neither species richness nor species diversity was correlated with altitude, longitude, latitude, or sampling method. This may be related to the small number of specimens or the small number of sampling sites.

Vector surveillance programs, ranging from local to regional levels, are required for monitoring the introduction of emerging and reemerging diseases and should be continuously carried out by different study groups.

\section{Acknowledgments}

This study was supported partially by the Hacettepe University Research Fund (Project Nos. 09 D07 601002 and 011 D06 601 004). The authors would like to thank Prof Zafer Karaer, Dr Esin Güven, and Ömer Orkun of the Veterinary Faculty of Ankara University for support, and Salim Çalış for technical assistance during the field studies. The authors also thank Dr Çağatay Tavsanoğlu, Dr Arda Cem Kuyucu, and Meltem Top for their valuable comments on the manuscript.

Bursali A, Tekin S, Orhan M, Keskin A, Ozkan M (2010). Ixodid ticks (Acari: Ixodidae) infesting humans in Tokat Province of Turkey: species diversity and seasonal activity. J Vector Ecol 35: $180-186$.

Çiçek H (2004). Epizootiological studies on Haemaphysalis ticks in Ankara Province, Turkey. Turk J Vet Anim Sci 28: 107-113.

Estrada-Peña A (2001). Distribution, abundance and habitat preferences of Ixodes ricinus (Acari: Ixodidae) in northern Spain. J Med Entomol 38: 361-370.

Estrada-Peña A, Bouattour A, Camicas JL, Walker AR (2004). Ticks of Domestic Animals in the Mediterranean Region: A Guide to Identification of Tick Species. Zaragoza, Spain: University of Zaragoza.

Gargılı A, Kar S, Yılmazer N, Cerit C, Sönmez G, Şahin F, Günseli Alp H, Vatansever Z (2010). Evaluation of ticks biting humans in Thrace Province, Turkey. Kafkas Uni Vet Fak Derg 16: 141146. 
Gargılı A, Midilli K, Ergin S, Yılmaz G, Altaş K (2007). Türkiye Kenelerinde Kırım-Kongo Kanamalı Humması ve Tick-Borne Ensefalit Etkenlerinin Nested RT-PCR Yöntemiyle Aranması, Etkenlerin Moleküler Genotiplendirilmesi ve İnfeksiyon Odaklarının Belirlenmesi. Ankara, Turkey: TÜBİTAK Proje Raporu (SBAG-2882) (in Turkish).

Gargılı A, Vatansever Z, Alp HG (2006). Kırklareli ili köylerinde Kırım-Kongo vektörlerinin taranması ve Kırım-Kongo bilgilendirme semineri. Kırklareli, Turkey: Pendik Veteriner Kontrol ve Araştırma Enstitüsü, Kırklareli Ticaret Odası (in Turkish)

Ghosh Z, Bansal GC, Gupta D, Ray D, Khan MQ, Irshad H, Shahiduzzaman MD, Seitzer U, Ahned JS (2007). Status of tick distribution in Bangladesh, India and Pakistan. Parasitol Res 101: 207-216.

Güler S (1982). Ankara ve civarındaki koyun ve keçilerde kış Ixodidae'leri üzerine araştırmalar. Uludağ Üniv Vet Fak Derg 1: 45-54 (in Turkish).

Güner ES, Hashimoto N, Takada N, Kaneda K, Imai Y, Masuzawa $\mathrm{T}$ (2003). First isolation and characterization of Borrelia burgdorferi sensu lato strains from Ixodes ricinus ticks in Turkey. J Med Microbiol 52: 807-813.

Gunes T, Poyraz O, Vatansever Z (2011). Crimean-Congo hemorrhagic fever virus in ticks collected from humans, livestock, and picnic sites in the hyperendemic region of Turkey. Vector-Borne Zoonotic Dis 11: 1411-1416.

Hekimoglu O, Ozer N, Ergunay K, Ozkul A (2012). Species distribution and detection of Crimean Congo Hemorrhagic Fever Virus (CCHFV) in field collected ticks in Ankara Province, Central Anatolia, Turkey. Ex Appl Acarol 56: 175-184.

Hornok S, Farkas R (2009). Influence of biotope on the distribution and peak activity of questing ixodid ticks in Hungary. Med Vet Entomol 23: 41-46.

Jongejan F, Uilenberg G (2004). The global importance of ticks. Parasitology 129: 3-14.

Kar S, Dervis E, Akın A, Ergonul O, Gargili A (2013). Preferences of different tick species for human hosts in Turkey. Exp Appl Acarol 61: 349-355.

Karaer Z, Guven E, Nalbantoglu S, Kar S, Orkun O, Ekdal K, Kocak A, Akcay A (2011). Ticks on humans in Ankara, Turkey. Exp Appl Acarol 54: 85-91.

Karaer Z, Yukarı BA, Aydın L (1997). Türkiye keneleri ve vektörlükleri. In: Özcel A, Daldal N, editors. Parazitoloji'de Artropod Hastalıkları ve Vektörler. İzmir, Turkey: Türkiye Parazitoloji Derneği Yayını, pp. 363-434.

Li X, Dunley JE (1998). Optimal sampling and spatial distribution of Ixodes pacificus, Dermacentor occidentalis and Dermacentor variabilis ticks (Acari: Ixodidae). Exp Appl Acarol 22: 233-248.

Masuzawa T, Şen E, Kharitonenkov I, Kadosaka T (2005). Tickborne pathogens, B. burgdorferi found in Turkey and Moscow, Russia on the border of Europe and Asia. In: FEMS Symposium 'Vector-borne Emerging and Re-emerging Pathogens and Their Infections' Abstracts Book. İstanbul, Turkey: FEMS, Turk Mikrobiyoloji Cemiyeti, p. 18.
Sayın F, Karaer Z (1987). Ankara Yöresinde Sığır ve Koyunlarda Kene Enfestasyonu Üzerinde Araştırmalar. Türk Veteriner Hekimleri Birliği I. Bilim Kongresi, Bildiri Özetleri. Tebliğ No. 24. Ankara, Turkey: Türk Veteriner Hekimleri Birliği (in Turkish).

Şen E (2007). Küresel ısınmanın kenelerle taşınan infeksiyonlara etkisi. Turk Mikrobiyo Cem Derg 37: 176-188 (in Turkish).

Şen E, Masuzawa T, Kadosaka T (2005). Environmental factors in the emergence and re-emergence of vector-borne pathogens in Turkey. In: FEMS Symposium 'Vector-borne Emerging and Re-emerging Pathogens and Their Infections' Abstracts Book. İstanbul, Turkey: FEMS, Turk Mikrobiyoloji Cemiyeti, p. 16.

Sonenshine DE (1991). Biology of Ticks. Volume 1. New York, NY, USA: Oxford University Press.

Tekin S, Bursali A, Mutluay N, Keskin A, Dundar E (2012). CrimeanCongo hemorrhagic fever virus in ixodid tick species from a highly endemic area. Vet Parasitol 186: 546-552.

Tonbak S, Aktas M, Altay K, Azkur KA, Kalkan A, Bolat Y, Dumanli N, Ozdarendeli A (2006). Crimean-Congo hemorrhagic fever virus: genetic analysis and tick survey in Turkey. J Clin Microbiol 44: 4120-4124.

Vatansever Z, Gargili A, Aysul NS, Sengoz G, Estrada-Peña A (2008). Ticks biting humans in the urban area of Istanbul. Parasitol Res 102: 551-553.

Walker AR, Bouattour A, Camicas JL, Estrada-Peña A, Horak IG, Latif AA, Pegram RG, Preston PM (2003). Ticks of Domestic Animals in Africa: A Guide to Identification of Species. Edinburgh, UK: University of Edinburgh.

Yay M, Yazar S, Aydın L, Şahin İ (2004). Investigation of tick species on sheep and cattle around of Kayseri. Erciyes Univ J Health Sci 13: 25-29 (in Turkish with English summary).

Yesilbag K, Aydin L, Dincer E, Alpay G, Girisgin AO, Tuncer P, Ozkul A (2013). Tick survey and detection of Crimean Congo hemorrhagic fever virus in tick species from a non-endemic area, South Marmara region, Turkey. Exp Appl Acarol 60: 253-261.

Yukarı BA, Umur Ş (2002). Burdur yöresindeki sığır, koyun ve keçilerde kene (Ixodoidea) türlerinin yayılışı. Turk J Vet Anim Sci 26: 1263-1270 (in Turkish).

Zahler M, Filippova NA, Morel PC, Gothe R, Rinder H (1997). Relationships between species of the Rhipicephalus sanguineus group: a molecular approach. J Parasitol 83: 302-306.

Zeybek H, Kalkan A (1984). Ankara yöresinde mera kenelerinin yayılışı ve mevsimlerle ilişkisi. Etlik Vet Mikrob Enst Derg 5: 14-21 (in Turkish). 